\title{
Prevalence of $\mathrm{Au}-\mathrm{Ag}$ and $\mathrm{Au}-\mathrm{Ab}$ in transfused children with thalassaemia in Greece
}

\author{
CHRISTOS KATTAMIS, VASILIKI SYRIOPOULOU, YIOULI DAVRI-KARAMOUZI, \\ DEMETRIOS DEMETRIOU, and NICHOLAS MATSANIOTIS \\ From the Department of Paediatrics, 'St. Sophie's' Children's Hospital, Athens University, Greece
}

\begin{abstract}
Kattamis, C., Syriopoulou, V., Davri-Karamouzi, Y., Demetriou, D., and Matsaniotis, N. (1974). Archives of Disease in Childhood, 49, 450. Prevalence of $\mathbf{A u}-\mathbf{A g}$ and $\mathbf{A u}-\mathbf{A b}$ in transfused children with thalassaemia in Greece. The prevalence of Australia-antigen and -antibody was studied in 196 patients with thalassaemia, aged 10 months to 14 years. $\mathrm{Au}-\mathrm{Ag}$ was detected in 14 patients $(7 \%)$ and $\mathrm{Au}-\mathrm{Ab}$ in $63(32 \%)$. The prevalence of $\mathrm{Au}-\mathrm{Ag}$ was in inverse relation to the age of the patients and in direct relation to the number of units of transfused blood. By contrast, the prevalence of $\mathrm{Au}-\mathrm{Ab}$ was directly related to both the age and the number of transfused blood units. Au-Ab was detected in $61 \%$ of patients who had received more than 60 units of blood, but in only $11 \%$ of patients who had received less than 20 units. No sex difference was found in the prevalence of $\mathrm{Au}-\mathrm{Ag}$ and $\mathrm{Au}-\mathrm{Ab}$.

Only 2 patients with $\mathrm{Au}-\mathrm{Ag}$ were without clinical or biochemical evidence of hepatitis; in all the remaining 12 patients $\mathrm{Au}-\mathrm{Ag}$ persisted throughout the period of observation of from 5 to 18 months. During the same period Au-Ab was found to persist in all patients in whom it was detected.

The persistence of $\mathrm{Au}-\mathrm{Ag}$ and the synthesis of $\mathrm{Au}-\mathrm{Ab}$ appear to be related to (a) repeated infection with type $B$ virus and (b) the host's immune response.
\end{abstract}

Epidemiological, clinical, biochemical, and histological studies have shown that the presence of Australia antigen ( $\mathrm{Au}-\mathrm{Ag})$ is associated with infection with the virus of serum or type $B$ hepatitis (Krugman, Giles, and Hammond, 1967, Blumberg et al., 1967). Though type B hepatitis can be transmitted by the oral route (Krugman and Giles, 1970), the most common route of infection is parenteral, mainly by transfusion of infected blood.

$\mathrm{Au}-\mathrm{Ag}$ is detected during the incubation period and before the appearance of clinical or biochemical findings of hepatitis, and disappears usually within a few days or weeks. Some individuals carry $\mathrm{Au}-\mathrm{Ag}$ for a long time; these long-term carriers are, as a rule, healthy; they have no clinical or biochemical evidence of hepatitis and may spread the virus to susceptible individuals. In some populations (mostly tropical) up to $20 \%$ of normal adults have been found to carry $\mathrm{Au}-\mathrm{Ag}$ in their blood (Blumberg, Sutnick, and London, 1970).

The factors which lead to an individual becoming a long-term healthy $\mathrm{Au}-\mathrm{Ag}$ carrier are unknown; it

Received 14 November 1973. has been postulated that these factors are genetically determined by an autosomal recessive gene (Vierucci et al., 1972).

The factors regulating the synthesis of $\mathrm{Au}-\mathrm{Ab}$ are also unclear. Very few patients with $\mathrm{Au}-\mathrm{Ag}$ associated hepatitis synthesize $A u-A b$, and this antibody is rarely detected in healthy individuals. It has been frequently detected, however, in hypertransfused patients with haemophilia, aplastic anaemia, or thalassaemia.

So far a limited number of studies on the incidence of $\mathrm{Au}-\mathrm{Ag}$ and $\mathrm{Au}-\mathrm{Ab}$ in thalassaemia have been reported and their results have been equivocal (Economidou et al., 1970, Vierucci et al., 1972).

This paper presents our findings on the prevalence of $\mathrm{Au}-\mathrm{Ag}$ and $\mathrm{Au}-\mathrm{Ab}$ in 196 transfused children with thalassaemia in Greece. The study was made in an attempt to define (a) the rate of infection with type B viral hepatitis by transfusion of patients with thalassemia, (b) the duration of $\mathrm{Au}-\mathrm{Ag}$ antigenaemia, and (c) the factors enhancing the synthesis of $A u-A b$ and the persistence of $A u-A b$ in thalassaemic patients. 


\section{Material and methods}

196 patients (94 males and 102 females) with homozygous $\beta$-thalassaemia, aged 10 months to 14 years, attending the Haemolytic Anaemia Unit of the Paediatric Department of Athens University, were studied. They were on different transfusion regimens in regard to pretransfusion $\mathrm{Hb}$ levels. However, most were on a frequent transfusion regimen, i.e. they were transfused when the $\mathrm{Hb}$ level fell to $8 \mathrm{~g} / 100 \mathrm{ml}$.

More than 600 serum samples collected from these patients before transfusion on several occasions were tested for $\mathrm{Au}-\mathrm{Ag}$ and $\mathrm{Au}-\mathrm{Ab}$ by immunoelectroosmophoresis, using $1 \%$ agarose in barbitone buffer, $p \mathrm{H}$ $8 \cdot 2$, and ionic strength $0.05 \mu \mathrm{m}$. The antibody used was obtained from pooled sera from patients with homozygous $\beta$-thalassaemia who were frequently transfused.

\section{Results}

Prevalence of Au-Ag and Au-Ab. The results on the prevalence $\mathrm{Au}-\mathrm{Ag}$ and $\mathrm{Au}-\mathrm{Ab}$ among 196 children studied are summarized in Table I.

\section{TABLE I}

Prevalence of $A u-A g$ and $A u-A b$ in 196 children with $\beta$-thalassaemia

\begin{tabular}{l|c|c|c|c|c}
\hline \multirow{2}{*}{ Patients } & \multicolumn{2}{|c|}{$\begin{array}{c}\text { Detection of } \\
\text { Au-Ag }\end{array}$} & \multicolumn{2}{|c}{$\begin{array}{c}\text { Detection of } \\
\text { Au-Ab }\end{array}$} \\
\cline { 2 - 5 } cases & $\begin{array}{c}\text { No. of } \\
\text { cases }\end{array}$ & $\%$ & $\begin{array}{c}\text { No. of } \\
\text { cases }\end{array}$ & $\%$ \\
\hline $\begin{array}{l}\text { Males } \\
\text { Females }\end{array}$ & 94 & 7 & 7 & 30 & 32 \\
\hline Total & 102 & 7 & 7 & 33 & 32 \\
\hline
\end{tabular}

$\mathrm{Au}-\mathrm{Ag}$ was detected in $14(7 \%)$ and $\mathrm{Au}-\mathrm{Ab}$ in 63 $(32 \%)$ children. No difference in the prevalence of either $\mathrm{Au}-\mathrm{Ag}$ or $\mathrm{Au}-\mathrm{Ab}$ was found between boys and

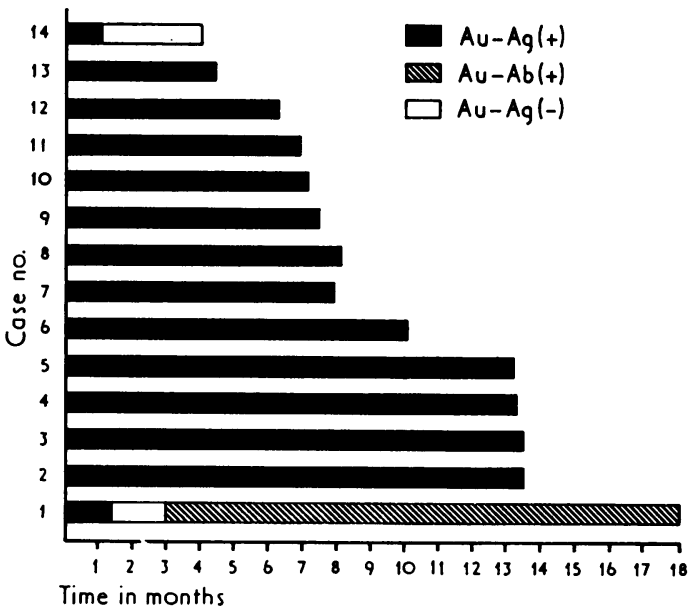

FIG.-Persistence of Au-antigenaemia in 14 patients with thalassaemia.

girls. None of these patients carried both $\mathrm{Au}-\mathrm{Ag}$ and $\mathrm{Au}-\mathrm{Ab}$.

The persistence of $\mathrm{Au}-\mathrm{Ag}$ in the 14 patients is illustrated in the Fig. Only 2 of these patients (Cases 1 and 14) had clinical and biochemical evidence of hepatitis and in both Au-Ag disappeared within about 1 month. In Case 1 antibody was detected after 2 months.

The remaining 12 patients had no clinical or biochemical evidence of hepatitis but $\mathrm{Au}-\mathrm{Ag}$ persisted throughout the observation period, which varied from 5 to 18 months.

Relation of prevalence of Au-Ag and Au-Ab to age and number of transfused blood units. This is shown in Table II. It is evident that the

\section{TABLE II}

Relation of prevalence of $A u-A g$ and $A u-A b$ to age and number of transfused blood units

\begin{tabular}{|c|c|c|c|c|c|c|c|c|c|}
\hline \multirow{2}{*}{ Groups } & \multirow{2}{*}{$\begin{array}{l}\text { Total no. } \\
\text { of cases }\end{array}$} & \multicolumn{2}{|c|}{ Detection of Au-Ag } & \multicolumn{2}{|c|}{$\begin{array}{l}\text { Statistical analysis } \\
\text { by } \chi^{2}\end{array}$} & \multicolumn{2}{|c|}{ Detection of $\mathrm{Au}-\mathrm{Ab}$} & \multicolumn{2}{|c|}{$\begin{array}{l}\text { Statistical analysis } \\
\text { by } x^{2}\end{array}$} \\
\hline & & No. of cases & $\%$ & Groups & $\mathbf{P}$ & No. of cases & $\%$ & Groups & $\mathbf{P}$ \\
\hline $\begin{array}{cl}\text { Age } & (\mathrm{yr}) \\
\text { I } & 1-4 \\
\text { II } & 5-8 \\
\text { III } & 9-14\end{array}$ & $\begin{array}{l}58 \\
98 \\
40\end{array}$ & $\begin{array}{l}6 \\
7 \\
1\end{array}$ & $\begin{array}{r}10 \\
7 \\
2\end{array}$ & $\begin{array}{l}\text { I:II } \\
\text { II:III } \\
\text { I:III }\end{array}$ & $\begin{array}{l}<0.3 \\
<0.3 \\
<0.2\end{array}$ & $\begin{array}{r}8 \\
33 \\
22\end{array}$ & $\begin{array}{l}14 \\
34 \\
55\end{array}$ & $\begin{array}{l}\text { I:II } \\
\text { II:III } \\
\text { I:III }\end{array}$ & $\begin{array}{l}<0.01 \\
<0.01 \\
<0.001\end{array}$ \\
\hline $\begin{array}{l}\text { Transfusions } \\
\text { A } 0-20 \\
\text { B } 21-40 \\
\text { C } 41-60 \\
\text { D }>60\end{array}$ & $\begin{array}{l}53 \\
80 \\
22 \\
41\end{array}$ & $\begin{array}{l}7 \\
6 \\
1 \\
0\end{array}$ & $\begin{array}{r}13 \\
7 \\
4 \\
0\end{array}$ & $\begin{array}{l}A: B \\
B: C \\
C: D \\
A: D\end{array}$ & $\begin{array}{l}<0.2 \\
<0.8 \\
<0.05 \\
<0.02\end{array}$ & $\begin{array}{r}6 \\
23 \\
9 \\
25\end{array}$ & $\begin{array}{l}11 \\
29 \\
41 \\
61\end{array}$ & $\begin{array}{l}A: B \\
B: C \\
C: D \\
A: D\end{array}$ & $\begin{array}{l}<0.001 \\
<0.3 \\
<0.001 \\
<0.001\end{array}$ \\
\hline
\end{tabular}


incidence of $\mathrm{Au}-\mathrm{Ag}$ decreases, whereas that of $\mathrm{Au}-\mathrm{Ab}$ increases with increasing age.

The increase in the incidence of $\mathrm{Au}-\mathrm{Ab}$ was more impressive in the older group (9-14 years) of patients with thalassaemia; in this group the incidence of $\mathrm{Au}-\mathrm{Ab}$ was much higher $(55 \%)$ than in the younger age group (14\%).

The incidence of $\mathrm{Au}-\mathrm{Ab}$ was proportional to the amount of blood transfused, whereas the incidence of $\mathrm{Au}-\mathrm{Ag}$ appeared to be inversely proportional. Thus, the incidence of $\mathrm{Au}-\mathrm{Ag}$ was considerably higher in those patients who had received less than 20 units of blood, than in those who had received 41 to 60 or $>60$ blood units (Table II). In fact, the incidence of $\mathrm{Au}-\mathrm{Ag}$ dropped to zero in the last group $(\mathrm{P}<0 \cdot 02)$.

On the contrary, the incidence of $\mathrm{Au}-\mathrm{Ab}$ was considerably higher in the patients who had received more than 60 blood units. In this group the prevalence of $\mathrm{Au}-\mathrm{Ab}$ was $61 \%$, it was $11 \%$ in patients who had received 0 to 20 blood units, $29 \%$ in those who had received 21 to 40 units, and $41 \%$ in those who had received 41 to 60 units (Table II). In all patients the antibody, once detected, persisted throughout the observation period.

\section{Discussion}

Transfused patients with thalassaemia are in serious danger of infection with type $B$ viral hepatitis, especially in countries where the incidence of healthy carriers of type B virus as determined by the detection of $\mathrm{Au}-\mathrm{Ag}$ is high; in Greece the incidence of $\mathrm{Au}-\mathrm{Ag}$ in healthy blood donors has been estimated to be 3\% (Hadziyannis et al., 1970). However, we were impressed by the fact that transfused children with thalassaemia, closely followed-up at our unit, rarely showed clinical signs of viral hepatitis, and when they did the course of hepatitis was mild without serious complications, at least during the acute phase.

As indicated by the results of this study, the rate of infection with type $B$ viral hepatitis, as determined by both the incidence of $\mathrm{Au}-\mathrm{Ag}$ and $\mathrm{Au}-\mathrm{Ab}$, is extremely high. Nearly $40 \%$ of our patients had clear evidence of infection. A similar rate of infection was found in another series of Greek patients with thalassaemia, but a lower prevalence of $\mathrm{Au}-\mathrm{Ag}(2 \%)$ and a higher prevalence of $\mathrm{Au}-\mathrm{Ab}$ (40\%) was reported (Economidou et al., 1970). In Italy the rate of infection with viral hepatitis in thalassaemic patients, though generally high, is lower than it is in Greece (Vierucci et al., 1972).

Epidemiological and clinical studies have shown an enormous variation in host response to infection with type B viral hepatitis, from acute hepatitis to the chronic carrier state of $\mathrm{Au}-\mathrm{Ag}$ without evidence of hepatitis (Blumberg et al., 1970). It has also been shown in experiments using volunteers that $0.01 \mathrm{ml}$ of icterogenic serum is as effective in causing infection as $\mathbf{2 0 0}$ times this amount (Cossart, 1972). Hence, it may be assumed that in practically any unit of blood with $\mathrm{Au}-\mathrm{Ag}$ the effective amount of antigen is considerable. If this be true, the effect of transfusion of infected blood in patients with thalassaemia is determined mainly by host factors. In this respect, transfused patients with thalassaemia may be considered as an experimental model for the study of some of the unknown factors which determine the variable clinical response to type $\mathbf{B}$ viral infection.

One point which may lead to speculation is the prevalence and persistence of $\mathrm{Au}-\mathrm{Ag}$ in our patients. In only 2 cases was $\mathrm{Au}-\mathrm{Ag}$ associated with clinical symptoms and laboratory findings of liver involvement. In both these patients $\mathrm{Au}-\mathrm{Ag}$ disappeared rapidly and in 1 of them it was followed by the production of $\mathrm{Au}-\mathrm{Ab}$. In the remaining 12 patients $\mathrm{Au}-\mathrm{Ag}$ was not associated with either apparent clinical signs or biochemical evidence of liver impairment, and it persisted for the whole period of observation which varied between 5 and 18 months.

The persistence of $\mathrm{Au}-\mathrm{Ag}$ in these patients is in contrast with the situation in acute viral hepatitis in which the presence of $\mathrm{Au}-\mathrm{Ag}$ is transient and is detectable only for days or weeks (London, Sutnick, and Blumberg, 1969). On the other hand, the absence of clinical and biochemical evidence of hepatitis is similar to the situation in healthy carriers of $\mathrm{Au}-\mathrm{Ag}$. In our opinion, the persistence of $\mathrm{Au}-\mathrm{Ag}$ in these patients can be explained only by assumming that such patients belong to a population which is susceptible to developing the state of long-term healthy carrier.

Blumberg et al. (1967) advanced the hypothesis that the persistence of the antigenaemia in some patients (i.e. with Down's syndrome, leukaemia) results from impairment of the immune system, probably impairment of cellular immunity. However, for the time being it is not clear whether the persistence of antigenaemia in patients with thalassaemia is due to recurrent infection transmitted by transfusion of infected blood, to the persistence of a single infection, or both. The answer may be found by long-term follow-up of $\mathrm{Au}-\mathrm{Ag}$ positive thalassaemic patients, who upon detection of $\mathrm{Au}-\mathrm{Ag}$ would be transfused with noninfected blood selected carefully by the most sensitive screening procedures in order to reduce the possibility of reinfection.

Another point which is difficult to explain is the 
absence of clinical signs in most patients of this series infected by type B hepatitis virus. Undoubtedly, the young age of the patients was an important factor, since it is well known that hepatitis runs a very mild course and frequently is anicteric in children. Furthermore, in our experience there is no demonstrable difference in the clinical course and prognosis of hepatitis associated with $\mathrm{Au}-\mathrm{Ag}$ and that not associated with $\mathrm{Au}-\mathrm{Ag}$. Another factor which could modify the clinical course of hepatitis in our patients is the fact that they were transfused with whole blood. Though the evidence on the preventive value of $\gamma$-globulin in type B hepatitis is still conflicting, the possibility of a favourable effect of regular transfusion of considerable amounts of plasma cannot be excluded in our patients.

The long-term prognosis of these patients, in whom the type $B$ hepatitis apparently ran a mild clinical course with no serious complications during the acute phase, cannot be predicted with certainty. Vierucci et al. (1972) postulated that the persistence of $\mathrm{Au}-\mathrm{Ag}$ in thalassaemic children contributes to early mortality. We were not able to confirm this assumption for we had no deaths during the observation period in our series, which consisted mainly of children below 12 years of age; it is our impression that some older patients developed clinical and biochemical signs of cirrhosis earlier than would have been expected from the number of transfusions and the degree of haemosiderosis, and that cirrhosis was associated with previous infection with type B viral hepatitis, since most of these patients had $\mathrm{Au}-\mathrm{Ab}$ in their serum.

We were unable to confirm either the higher incidence of $\mathrm{Au}-\mathrm{Ag}$ in males or the higher frequency of $\mathrm{Au}-\mathrm{Ab}$ in females in published reports. In our series there were no sex differences in the incidence of $\mathrm{Au}-\mathrm{Ag}$ and $\mathrm{Au}-\mathrm{Ab}$.

The last point to discuss is the factors enhancing $\mathrm{Au}-\mathrm{Ab}$ synthesis. $\mathrm{Au}-\mathrm{Ab}$ is detected in healthy individuals rarely and only exceptionally in patients with type B hepatitis. Undoubtedly the regulation of antibody synthesis is multifactorial, but the function of immune mechanism of the host and the way by which it is stimulated by the infectious agent are of primary importance. Clinical and experi- mental studies have shown that $\mathrm{Au}-\mathrm{Ab}$ is usually produced after repeated infection with type B hepatitis. This explains the high incidence $(61 \%)$ of $\mathrm{Au}-\mathrm{Ab}$ in our patients who had received more than 60 blood units and its very low incidence $(13 \%)$ in those who had received less than 20 blood units. In view of the high incidence of $\mathrm{Au}-\mathrm{Ag}$ among blood donors in Greece, it may be assumed that hypertransfused patients with thalassaemia have repeatedly received infected blood. We are led to conclude that repeated stimulation of the host's immune system by $\mathrm{Au}-\mathrm{Ag}$ appears to be one of the factors regulating the production of Au-antibody.

We are grateful to the medical and nursing staffs of the Department of Paediatrics for help in the treatment of thalassaemic patients, and to Dr. Cleopatra OeconomouMavrou for editorial work.

\section{REFERENCES}

Blumberg, B. S., Gerstley, B. J. S., Hungerford, D. A., London, W. T., and Sutnick, A. I. (1967). A serum antigen (Australia antigen) in Down's syndrome, leukemia, and hepatitis. Annals of Internal Medicine, 66, 924.

Blumberg, B. S., Sutnick, A. I., and London, W. T. (1970). Australia antigen as a hepatitis virus: variation in host response. American Fournal of Medicine, 48, 1.

Cossart, Y. E. (1972). What determines the incidence of serum hepatitis after blood transfusion? American fournal of Diseases of Children, 123, 354.

Economidou, J., Konstantoulakis, M., Avgustaki, G., Taylor, P. E., Zuckerman, A. J., Baines, P. M., and Bryceson, M. A. (1970). The incidence of hepatitis-associated antigen and antibody in patients with thalassemia in Greece. (Abst.) XIII Congress of Haematology, Munich, August 1970, p. 402.

Hadziyannis, S. J., Merikas, G. E., Afroudakis, A. P., Panetsos, S., and Moussouros, A. (1970). Observations on Australia (Au) antigen in Greece. Iatriki, 18, 221.

Krugman, S., and Giles, J. P. (1970). Viral hepatitis; new light on an old disease. Fournal of the American Medical Association, 212, 1019.

Krugman, S., Giles, J. P., and Hammond, J. (1967). Infectious hepatitis. Evidence for two distinctive clinical, epidemiological, and immunological types of infection. Fournal of the American Medical Association, 200, 365.

London, W. T., Sutnick, A. I., and Blumberg, B. S. (1969). Australia antigen and acute viral hepatitis. Annals of Internal, Medicine, 70, 55.

Vierucci, A., London, W. T., Blumberg, B. S., Sutnick, A. I., and Ragazzini, F. (1972). Australia antigen and antibody in transfused children with thalassaemia. Archives of Disease in Childhood, 47, 760.

Correspondence to Dr. C. Kattamis, Athens University Department of Paediatrics, 'St. Sophie's' Children's Hospital, Athens 608, Greece. 